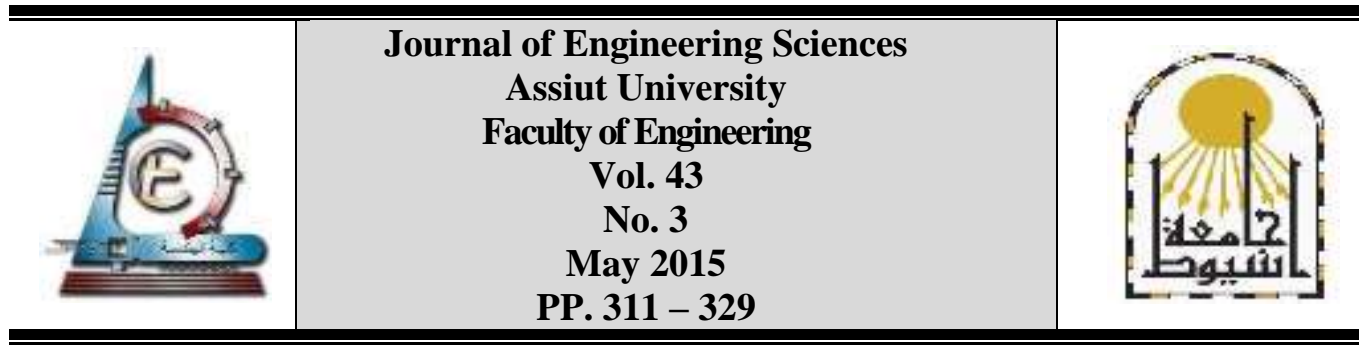

\title{
STUDYING THE EFFECT OF DIFFERENT CONFIGURATIONS AND POSITIONS OF SILL OVER STILLING BASIN ON FLOW CHARACTERISTICS BEHIND RADIAL GATE, (CASE STUDY: NAGAA HAMMADI REGULATOR)
}

\author{
Yasser A. Mohamed ${ }^{1}$, Yasser K. Saleh ${ }^{2}$, and Abdelazim M. Ali ${ }^{3}$ \\ ${ }^{I}$ college of engineering, Zagazaig University \\ ${ }^{2}$ High Institute of Technology, $10^{\text {th }}$ of Ramadan, Egypt \\ ${ }^{3}$ Hydraulic Institute, Ministry of water resources and irrigation, Egypt
}

(Received 3 May 2015; Revised 23 May 2015; Accepted 3 June 2015)

\begin{abstract}
Barrage Regulators are considered one of the most important hydraulic structures that used to control the released discharge and upstream and downstream water levels. New barrages are constructed on the River Nile instead of the oldest ones, which are not able to resist the requirements of increasing head difference upon their gates. The present study was focused on investigating experimentally the effect of sill over stilling basin of Nagaa Hammadi regulator on the length of reverse flow behind sill, velocity at the end of stilling basin, energy dissipation, length of submerged hydraulic jump and scour formation downstream regulator apron. Experimental work was carried out on a re-circulating flume with $1.0 \mathrm{~m}$ wide, $26.0 \mathrm{~m}$ long and $1.2 \mathrm{~m}$ deep, with discharges range from 40 to $190 \mathrm{l} / \mathrm{s}$. It is found that the sill over stilling basin has great effect on flow characteristic and local scour depth formed downstream regulator especially for sill with right and slopped faces at the upstream and downstream, respectively. The present study shows that, the reverse flow length downstream sill decreases as the submergence ratio and Froude number increase. In addition, using sill with right upstream and slopped face at downstream with $\mathrm{L}_{\mathrm{s}} / \mathrm{L}=0.6$, reduces the length of submerged hydraulic jump by $59 \%$ in average and thus leads to decrease stilling basin length. Local scour depth downstream hydraulic structures were reduced by $43 \%$. Moreover, the energy dissipation was increased by $30 \%$ compared to the no sill case. Finally, Empirical equations are developed using multiple linear regressions analysis.
\end{abstract}

Keywords: Submerged jump, barrage regulators, reverse flow, sill, Local scour, energy dissipation.

\section{Introduction}

Hydraulic jump is considered as an efficient tool for energy dissipation. Sills and baffles are provided to stilling basin to increase the energy dissipation efficiency, as well as to stabilize the hydraulic jump [1]. It was cleared for submerged hydraulic jump the jet

* Corresponding author.

Email address: Yasser_eng1997@yahoo.com 
mixing decreases when the submergence increases. This leads to less dissipation of energy compared with free hydraulic jumps, and the decay of the high velocity jet is retard $[2,3]$. So, Longer stilling basin is required for submerged hydraulic jump if used as energy dissipater compared to the free hydraulic jump. Large number of research studies, dealing with submerged hydraulic jump, was implemented. GovindaRao and Rajaratnam, [4] studied experimentally the submerged jump in rectangular basin. The submerged jump as the case of a plane turbulent wall was clarified by Rajaratnam [2]. Narasmhan and Bhargara [5] studied the pressure fluctuation in a submerged jump downstream of a sluice gate. McCorquodale and Khalifa [6] studied experimentally and theoretically the characteristics of submerged hydraulic jump in a radial basin. El-Azizy [7] and Abdel-Aal [8] studied experimentally the submerged hydraulic jump under different flow conditions. Long et al. [9], Fuxima and Prinos [10], and Ma et al. [11] clarified numerically the submerged hydraulic jump. Simth [12] and Ohtsu et al. [13] studied the submerged hydraulic jump below abrupt expansion. Flokstra [14] investigated a numerical model for submerged vanes. Brett et al. [15] investigated submerged and free natural hydraulic jumps in a bedrock step-pool mountain channel. Subhasish and Arindam [16] investigated the characteristics of turbulent flow in submerged jumps on rough beds. Ali and Mohamed [17] studied the effect of stilling basin shape on submerged jump characteristics. Experimental studies on submerged hydraulic jumps with baffle walls and blocks downstream of a sluice gate were carried out by Ali [18] and Habibzadeh et al. [19]. Hassan and Narayanan [20], Habib et al. [21] and El-Gamel et al. [22] studied experimentally the local scour depth downstream stilling basins. El-Gamel [23] investigated the effect of three lines of angle baffles on scour downstream hydraulic structures. Saleh et al. [24] studied the effect of sill on scour downstream expanding stilling basin. Subhasish and Airndam [25] investigated the scour downstream stilling basin due to the submerged horizontal jets. Tiwari at al. [26] investigated experimentally the effect of end sill on basin performance. Alireza et al. [27, 28] studied the performance of baffle blocks and mean flow in submerged hydraulic jump. Chen et al. [29] studied the characteristics of the velocity distribution in a hydraulic jump stilling basin with five parallel offset jets in a twin-Layer configuration. Tiwari [30] and Tiwari and Seema [31] investigated a design of stilling basin with end sill. Tiwari et al. [32] and [33] studied scour depth downstream stilling basin. The ministry of water resources and irrigation in Egypt, constructed many barrages along Nile River waterway, such as Esna 1908, Naga Hammai 1930, Assuit 1902, Delta 1939, Zefta 1902 and Idfena 1950. Some of these Barrages are replaced by other ones to overcome the requirements of increasing the head difference between the upstream and downstream water levels upon gates. The presented experimental studies aims to clarify the effect of different sill configurations and arrangements over the stilling basin of Naga Hammadi Barrage, on the flow characteristics such as, length of jump, energy dissipation, length of reverse flow behind the sill and local scour depth. This study is carried out under the effect of submerged hydraulic jumps. The reverse flow and near bed velocity are directed to explain the values of local scour depth downstream stilling basins.

\section{Experimental work}

The experiments were conducted using a $1.0 \mathrm{~m}$ wide, $26.0 \mathrm{~m}$ long and $1.2 \mathrm{~m}$ deep flume, photo (1). The flume is provided with a re-circulating system. Radial gate was constructed at a distance of about $12.0 \mathrm{~m}$ downstream the flume inlet. The side walls along 
Yasser A. Mohamed et al., studying the effect of different configurations and positions of sill ..........

the entire length of the flume are made of glass with steel-frames, to allow visual investigation of the flow patterns and stability of bed protection. The tail water depth is controlled by a tailgate located at the downstream end of the flume. The physical model was constructed with a scale of 1:21 to simulate one vent of Nagaa Hammadi regulator. Different models of sills over stilling basins were experimentally tested as shown in Table 1 , and Fig. 1. The sill under radial gate $\left(h_{g}\right)$ has constant height of $9 \mathrm{~cm}$. For each model, six different flow conditions and six different tail-water depths were tested, Table 2. The discharge was changed from $40 \mathrm{l} / \mathrm{s}$ to190 l/s, to cover the different submergence ratios. An ultrasonic flow-meter was used for measuring discharge. The specifications of the ultrasonic flowmeter are as following; (Type is 1010P/WP, Flow Velocity Range is \pm 12.2 $\mathrm{m} / \mathrm{s}$, and Flow Sensitivity is $0.015 \mathrm{~m} / \mathrm{s}$ even at zero flow). An electromagnetic currentmeter was used to measure the velocity at the end of stilling basin. This current-meter is a well-known as pipe flow-meter employing Faraday's Induction Law for velocity measurements of a conductive liquid moving through a magnetic field. It's accuracy is \pm $0.01 \mathrm{~m} / \mathrm{s} \pm 1 \%$ of value measured. Velocity measurement was conducted for each vertical at a fixed distance of $1.5 \mathrm{~cm}$ from the bed, to represent the near bed velocity values.

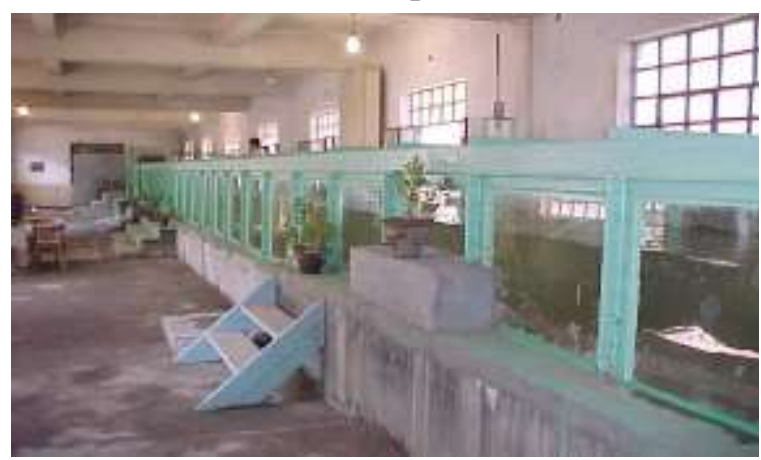

Photo. 1. General view of the flume

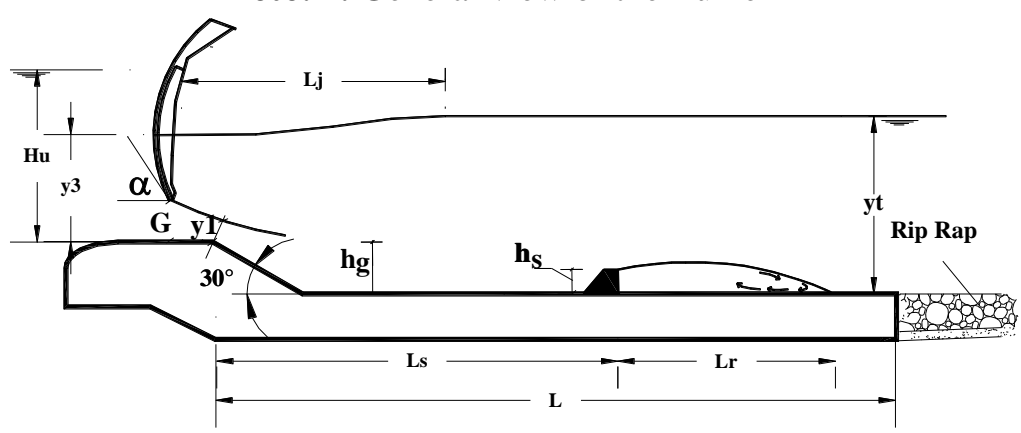

Fig. 1. Definition sketch of the experimental Model

Moreover, the electromagnetic current-meter was used to allocate the end of submerged jump. The electromagnetic current-meter traced the positive and negative values of the flow velocity on the top water surface layer; distance from zero velocity point to radial gate represents the length of the submerged hydraulic jump. During the experimental models, a reverse flow was observed downstream sill. The length of reverse flow behind sill was determined using the electromagnetic current-meter. The contraction coefficient under radial gate was calculated using Eq.1 as reported by Henderson [34], as follow;

$$
\mathrm{Cc}=1-0.75 \alpha+0.36 \alpha^{2}
$$


Where, $\mathrm{Cc}$ is the contraction coefficient and $\square$ is the angle shown in Fig. 1. The super critical flow depth $\mathrm{y}_{1}=\mathrm{G} \mathrm{Cc}$.

The apron was followed by a $4 \mathrm{~m}$ long movable bed covered by rip rap with $\mathrm{D}_{50}=1.5 \mathrm{~cm}$. $\mathrm{D}_{84} / \mathrm{D}_{50}=1.19$, and $\mathrm{D}_{85}(\mathrm{~mm})=18.5, \mathrm{D}_{50} / \mathrm{D}_{16}=1.31$. The movement of the bed material just downstream the apron was measured after each test run. The depth and length of the scouring hole was measured. The maximum local scour depth was measured using a point gauge with accuracy $\pm 0.1 \mathrm{~mm}$. After preliminary tests, the time duration for each experiment was taken as 8 hrs at which more than $90 \%$ of maximum scour depth is achieved.

Table 1.

Different experimental models.

\begin{tabular}{|c|c|c|c|c|}
\hline Model & $h_{s}(\mathrm{~cm})$ & $\mathbf{L}_{\mathrm{s}}(\mathrm{cm})$ & Configuration & Discharge( $1 / s)$ \\
\hline I & \multicolumn{3}{|c|}{ No-sill } & \multirow{7}{*}{$40-190$} \\
\hline II & 3.0 & 200 & & \\
\hline III & 4.5 & 200 & & \\
\hline IV & 9.0 & 200 & hs & \\
\hline V & 9.0 & 250 & \multirow{3}{*}{ hs } & \\
\hline VI & 9.0 & 200 & & \\
\hline VII & 9.0 & 150 & & \\
\hline
\end{tabular}

\section{Dimensional analysis}

The dimensional analysis was used to correlate the main hydraulic parameters with the independent variables as follow;

$$
E_{L} / E_{1}, L_{j} / y_{1}, D_{S} / D_{50} \text {, and } L_{o}=f\left(L_{S} / L, h_{o}, \emptyset, F_{r}, S\right)
$$

In which; $E_{L}$ is the difference between energy at the beginning $\left(E_{l}\right)$ and energy at the end of stilling basin $E_{2} ; L_{j}$ is the length of submerged jump; $y_{1}$ is the supercritical flow depth; $D_{s}$ is the maximum local scour depth; $D_{50}$ is the median size of riprap; $L_{o}$ is the relative length of reverse flow (ratio between reverse length downstream sill $L_{r}$ and stilling basin length $L$ ); $h_{o}$ is relative height of sill (ratio between sill height and drop height under gate, i.e. $\left.h_{s} / h_{g}\right) ; L_{s}$ is the distance from gate to sill; $\square$ is the sill shape indicator; $F_{r}$ is the Froude number $\left(v /\left(g y_{1}\right)^{\wedge} 0.5\right)$; and $\mathrm{S}$ is the submergence ratio (ratio between backup water depth and supercritical flow depth, i.e., $\left.y_{3} / y_{1}\right)$.

Table 2.

Experiments of models I and II

\begin{tabular}{|c|c|c|c|c|c|c|c|}
\hline \multirow{2}{*}{ Test No. } & $\begin{array}{c}\text { Discharge } \\
\mathbf{Q}\end{array}$ & $\begin{array}{c}\text { Gate opening } \\
\mathbf{G}\end{array}$ & $\boldsymbol{y}_{3}$ & $\boldsymbol{y}_{\boldsymbol{t}}$ & $\boldsymbol{L}_{\boldsymbol{j}}$ & $\boldsymbol{L}_{\boldsymbol{r}}$ & $\boldsymbol{D}_{\boldsymbol{s}}$ \\
& $\mathbf{1} / \mathbf{s}$ & $\mathbf{c m}$ & $\mathbf{c m}$ & $\mathbf{c m}$ & $\mathbf{c m}$ & $\mathbf{c m}$ & $\mathbf{c m}$ \\
\hline $\mathrm{I}-1$ & 40 & 2.7 & 27 & 41 & 185 & 0 & 0 \\
\hline $\mathrm{I}-2$ & 40 & 3 & 32 & 44 & 197 & 0 & 0 \\
\hline $\mathrm{I}-3$ & 40 & 3.3 & 35 & 48 & 206 & 0 & 0 \\
\hline $\mathrm{I}-4$ & 40 & 3.6 & 39 & 51 & 227 & 0 & 0 \\
\hline
\end{tabular}


Yasser A. Mohamed et al., studying the effect of different configurations and positions of sill ..........

\begin{tabular}{|c|c|c|c|c|c|c|c|}
\hline \multirow[t]{2}{*}{ Test No. } & $\begin{array}{c}\text { Discharge } \\
\text { Q }\end{array}$ & $\begin{array}{c}\text { Gate opening } \\
\text { G }\end{array}$ & $y_{3}$ & $y_{t}$ & $\boldsymbol{L}_{j}$ & $L_{r}$ & $D_{s}$ \\
\hline & $1 / s$ & $\mathbf{c m}$ & $\mathrm{cm}$ & $\mathbf{c m}$ & $\mathbf{c m}$ & $\mathbf{c m}$ & $\mathbf{c m}$ \\
\hline $\mathrm{I}-5$ & 40 & 3.9 & 42 & 54 & 244 & 0 & 0 \\
\hline I-6 & 40 & 4.2 & 46 & 57 & 258 & 0 & 0 \\
\hline $\mathrm{I}-7$ & 70 & 4.4 & 27 & 41 & 185 & 0 & 0 \\
\hline $\mathrm{I}-8$ & 70 & 4.7 & 31 & 44 & 203 & 0 & 0 \\
\hline I-9 & 70 & 5.2 & 36 & 48 & 222 & 0 & 1.8 \\
\hline I-10 & 70 & 5.6 & 40 & 51 & 240 & 0 & 2.8 \\
\hline I-11 & 70 & 6.1 & 42 & 54 & 251 & 0 & 4.1 \\
\hline $\mathrm{I}-12$ & 70 & 6.6 & 47 & 57 & 264 & 0 & 3.8 \\
\hline $\mathrm{I}-13$ & 100 & 6.1 & 25 & 41 & 190 & 0 & 5.4 \\
\hline I-14 & 100 & 6.4 & 29 & 44 & 202 & 0 & 4.7 \\
\hline I-15 & 100 & 6.7 & 33 & 48 & 219 & 0 & 4.8 \\
\hline I-16 & 100 & 7.6 & 38 & 51 & 230 & 0 & 4 \\
\hline I-17 & 100 & 8.2 & 42 & 54 & 246 & 0 & 4.3 \\
\hline I-18 & 100 & 9.1 & 45 & 57 & 260 & 0 & 3.7 \\
\hline I-19 & 130 & 8.3 & 24 & 41 & 201 & 0 & 5.9 \\
\hline I-20 & 130 & 8.7 & 29 & 44 & 215 & 0 & 5.8 \\
\hline I-21 & 130 & 9.4 & 32 & 48 & 227 & 0 & 6.2 \\
\hline I-22 & 130 & 10.2 & 37 & 51 & 245 & 0 & 6.1 \\
\hline I-23 & 130 & 11.1 & 40 & 54 & 264 & 0 & 4.9 \\
\hline I-24 & 130 & 12.1 & 44 & 57 & 277 & 0 & 4.2 \\
\hline I-25 & 160 & 10.1 & 22 & 41 & 193 & 0 & 6.9 \\
\hline I-26 & 160 & 10.9 & 28 & 44 & 210 & 0 & 7.1 \\
\hline I-27 & 160 & 11.5 & 33 & 48 & 225 & 0 & 6.4 \\
\hline I-28 & 160 & 12.5 & 37 & 51 & 238 & 0 & 6.1 \\
\hline I-29 & 160 & 13.3 & 41 & 54 & 258 & 0 & 5.7 \\
\hline I-30 & 160 & 14.8 & 45 & 57 & 270 & 0 & 5.6 \\
\hline I-31 & 190 & 11.8 & 20 & 41 & 188 & 0 & 10.2 \\
\hline I-32 & 190 & 12.9 & 26 & 44 & 205 & 0 & 9.3 \\
\hline I-33 & 190 & 14.2 & 32 & 48 & 215 & 0 & 9.1 \\
\hline I-34 & 190 & 14.9 & 37 & 51 & 230 & 0 & 7.1 \\
\hline I-35 & 190 & 16.2 & 41 & 54 & 242 & 0 & 9.1 \\
\hline I-36 & 190 & 16.7 & 45 & 57 & 257 & 0 & 7.2 \\
\hline II-1 & 40 & 2.7 & 30 & 41 & 1.77 & 65 & 0 \\
\hline II-2 & 40 & 3 & 34 & 44 & 1.88 & 75 & 0 \\
\hline II-3 & 40 & 3.3 & 38 & 48 & 2.12 & 97 & 0 \\
\hline II-4 & 40 & 3.6 & 42 & 51 & 2.2 & 108 & 0 \\
\hline II-5 & 40 & 3.9 & 44 & 54 & 2.26 & 125 & 0 \\
\hline II-6 & 40 & 4.2 & 47 & 57 & 2.32 & 130 & 0 \\
\hline II-7 & 70 & 4.6 & 30 & 41 & 1.81 & 75 & 0 \\
\hline
\end{tabular}


JES, Assiut University, Faculty of Engineering, Vol. 43, No. 3, May 2015, pp. $311-329$

\begin{tabular}{|c|c|c|c|c|c|c|c|}
\hline Test No. & $\begin{array}{c}\text { Discharge } \\
\text { Q }\end{array}$ & $\begin{array}{c}\text { Gate opening } \\
\text { G }\end{array}$ & $y_{3}$ & $y_{t}$ & $L_{j}$ & $L_{r}$ & $D_{s}$ \\
\hline & $1 / s$ & cm & $\mathrm{cm}$ & $\mathrm{cm}$ & cm & $\mathbf{c m}$ & $\mathbf{c m}$ \\
\hline II-8 & 70 & 4.9 & 34 & 44 & 2 & 94 & 0 \\
\hline II-9 & 70 & 5.3 & 38 & 48 & 2.17 & 112 & 0 \\
\hline II-10 & 70 & 5.6 & 42 & 51 & 2.33 & 128 & 0 \\
\hline II-11 & 70 & 6 & 44 & 54 & 2.43 & 132 & 0 \\
\hline II-12 & 70 & 6.5 & 48 & 57 & 2.58 & 146 & 0 \\
\hline II-13 & 100 & 6.1 & 30 & 41 & 1.78 & 75 & 0 \\
\hline II-14 & 100 & 6.6 & 34 & 44 & 1.89 & 90 & 0 \\
\hline II-15 & 100 & 7.1 & 38 & 48 & 1.98 & 105 & 0 \\
\hline II-16 & 100 & 7.6 & 41 & 51 & 2.07 & 120 & 0 \\
\hline II-17 & 100 & 8.5 & 44 & 54 & 2.22 & 133 & 0 \\
\hline II-18 & 100 & 9.3 & 48 & 57 & 2.28 & 145 & 0 \\
\hline II-19 & 130 & 8.8 & 30 & 41 & 1.68 & 50 & 0 \\
\hline II-20 & 130 & 9.3 & 34 & 44 & 1.81 & 63 & 0 \\
\hline II-21 & 130 & 10.2 & 38 & 48 & 1.92 & 75 & 0 \\
\hline II-22 & 130 & 11.2 & 42 & 51 & 2.05 & 92 & 0 \\
\hline II-23 & 130 & 12.2 & 44 & 54 & 2.15 & 102 & 0 \\
\hline II-24 & 130 & 13.3 & 47 & 57 & 2.26 & 110 & 0 \\
\hline II-25 & 160 & 10.4 & 30 & 41 & 1.42 & 9 & 5.6 \\
\hline II-26 & 160 & 11.3 & 34 & 44 & 1.53 & 17 & 4.3 \\
\hline II-27 & 160 & 12.2 & 38 & 48 & 1.65 & 30 & 4.1 \\
\hline II-28 & 160 & 13.1 & 42 & 51 & 1.78 & 45 & 3.7 \\
\hline II-29 & 160 & 14.2 & 44 & 54 & 1.85 & 55 & 2.8 \\
\hline II-30 & 160 & 15.9 & 47 & 57 & 1.97 & 68 & 2.7 \\
\hline II-31 & 190 & 12.3 & 30 & 41 & 1.41 & 0 & 9.1 \\
\hline II-32 & 190 & 13.3 & 34 & 44 & 1.48 & 0 & 10.1 \\
\hline II-33 & 190 & 14.7 & 38 & 48 & 1.55 & 0 & 8.6 \\
\hline II-34 & 190 & 15.7 & 42 & 51 & 1.65 & 0 & 7.7 \\
\hline II-35 & 190 & 17.3 & 44 & 54 & 1.68 & 0 & 4.7 \\
\hline II-36 & 190 & 18.8 & 47 & 57 & 1.77 & 0 & 6.1 \\
\hline
\end{tabular}

\section{Analysis and Discussions}

The experimental results were analyzed and discussed to clarify the performance of sill over stilling basin of Nagaa Hamadi barrage on the River Nile, Egypt. The effect of sill positions, heights, configuration, Froude number, and submergence ratios, on length of submerged jump, energy dissipation, reverse flow length downstream of sill and local scour depth downstream stilling basin were investigated. For typical cases, the relative energy loss $\left(E_{L} / E_{1}\right)$, and relative length of submerged jump $\left(L_{j} / y_{l}\right)$ are plotted versus Froude number $\left(F_{r}\right)$ for different submergence ratios (Model I, No-sill case), as shown in Figs. (2 and 3) respectively. It was found that, as the submergence ratio increases the relative energy loss decreases at which the jet mixing decreases. In addition, by increasing the submergence ratio 
Yasser A. Mohamed et al., studying the effect of different configurations and positions of sill ..........

for the same Froude number, the backup water depth increases leads to increase the length of submerged jet downstream the gate to have longer length of jump. The results of relative length of free hydraulic jump [35] and submerged radial basin [6] were presented in Fig. 3. The results show that, the relative length of submerged hydraulic jump for radial basin produces lower values compared to Model I (No-sill case) and that is due to the effect of sides through radial basin. The relative energy loss and relative length of submerged jump increase as the Froude number increase for all experimental models and different submerged ratios as shown in Figs. (4 and 5), and also other tested models (Model III, IV, V, VI and VII). The increase of Froude number generates more turbulence, and longer length for jet mixing that is leading to increase energy and length of jump. Fig. 6 presents the relationship between relative length of reverse flow behind sill and Froude number for case of Model II, $\left(h_{o}=0.33\right.$ ). It is found that $L_{o}$ increases by increasing $S$ and decreasing $F_{r}$.

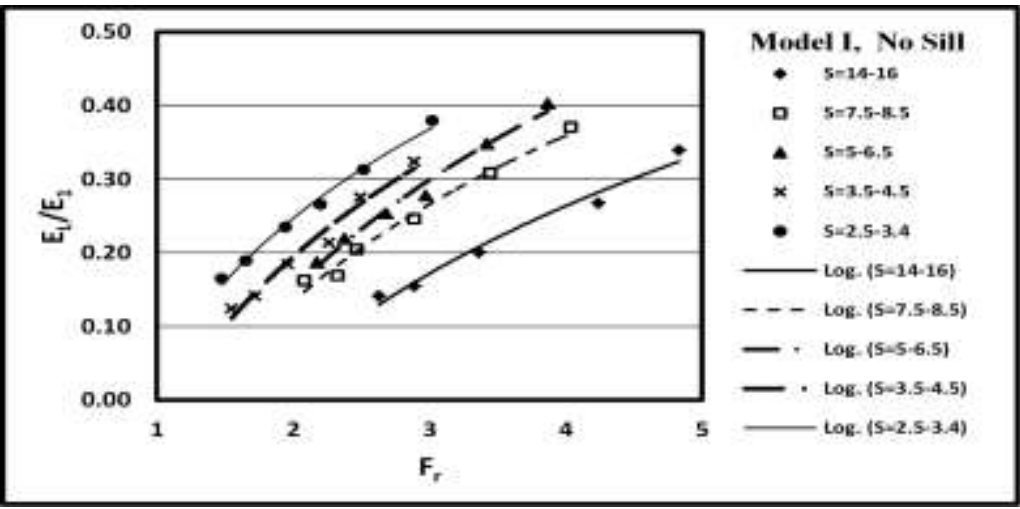

Fig. 2. Relationship between energy dissipation and Froude Number for Model I (Nosill case), and different submergence ratios $(S)$

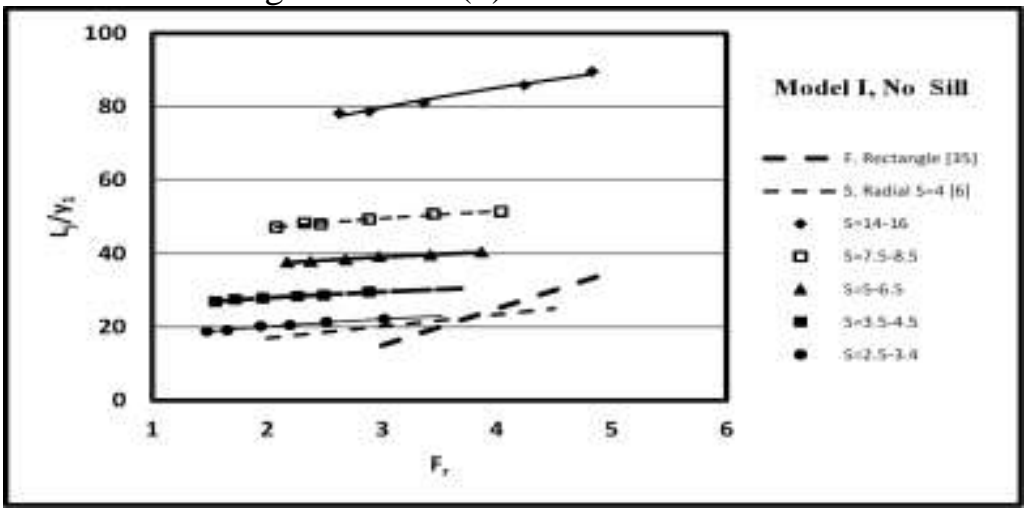

Fig. 3. Relationship between relative length of jump and Froude Number for Model I (No-sill case), and different submergence ratios $(S)$. 


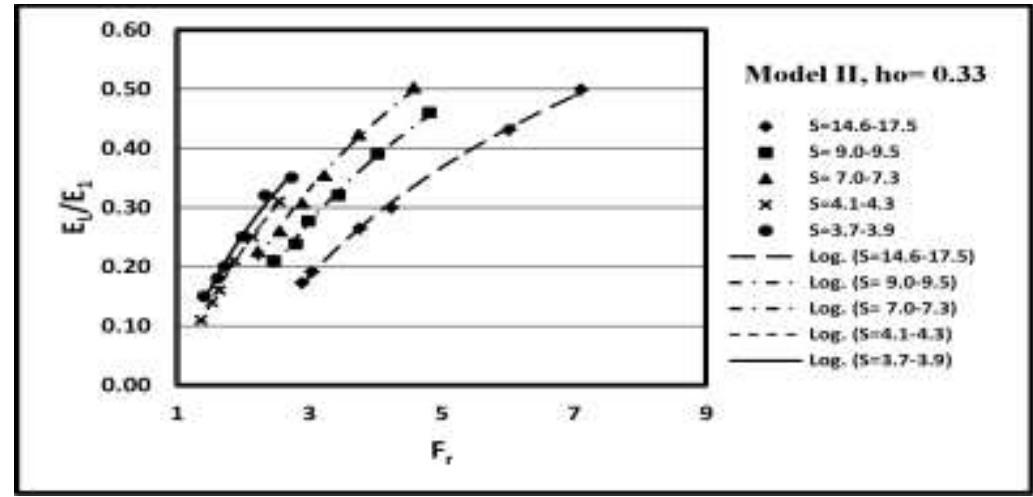

Fig. 4. Relationship between $E_{L} / E_{l}$ and $F_{r}$ for Model II $\left(h_{o}=0.33\right)$ and different submergence ratios $(S)$

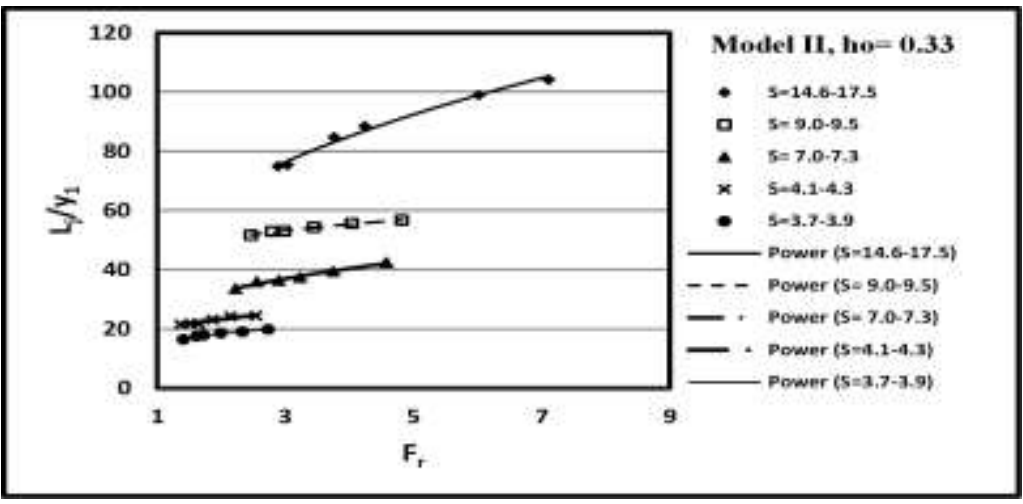

Fig. 5. Relationship between relative length of jump and Froude Number for Model II $\left(h_{o}=0.33\right)$ and different submergence ratios $(S)$

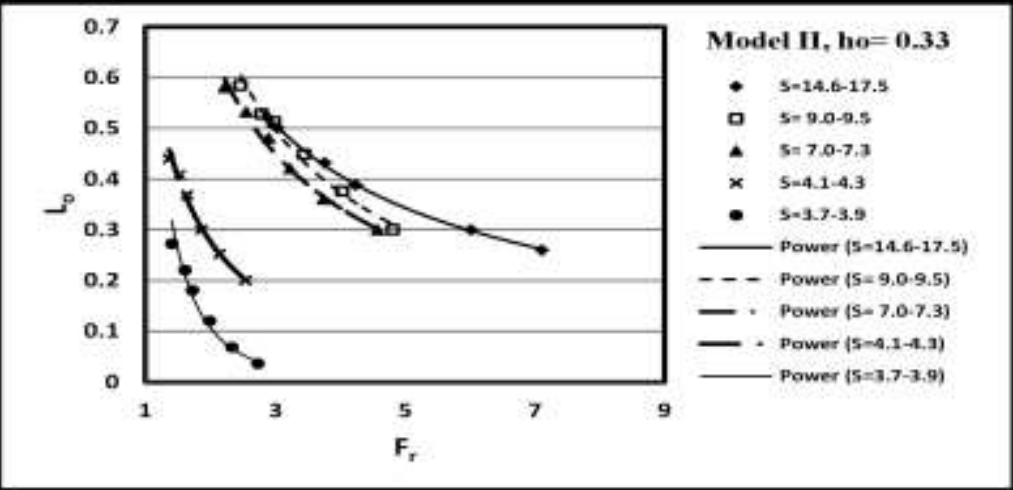

Fig. 6. Relationship between reverse length $L_{o}$ and Froude Number $F_{r}$ for Model II $\left(h_{o}=\right.$ $0.33)$ and different submergence ratios $(S)$

\subsection{Sill height}

The relative heights of sill $\left(h_{o}=\left(h_{s} / h_{g}\right)\right), 0,0.33,0.5$ and 1.0 are presented through models I, II, III, and IV, respectively (see Table1). For these experimental models, sill was fixed at $L_{s} / L=0.8$. Increasing of sill height leads to increase the relative energy loss and 
Yasser A. Mohamed et al., studying the effect of different configurations and positions of sill ..........

decrease the relative length of submerged hydraulic jump, as shown in Figs. 7 and 8, respectively. The sill over stilling basin is considered as a constriction to flow, that produces an opposite force to the flow jet downstream radial gate and more damping to the flow velocities will be occurred, so shorter length and higher energy dissipation will be produced. The energy dissipation was increased by $30 \%, 21 \%$ and $12 \%$ for ho $=1.0,0.5$ and 0.33 , respectively compared to the no sill case. While the relative length of submerged hydraulic jump was decreased by $58 \%, 48 \%$, and $41 \%$ for ho $=1.0,0.50$ and 0.33 , respectively compared to the no-sill case. The relative length of reverse flow increases as the height of sill increases, see Fig. 9. The effect of relative sill height over stilling basin on the local scour depth downstream stilling basin, for average submergence ratio $S=4$, was presented in Fig. 10. The relative local scour depth decreased by 43\%, 24\% and 10\% for ho $=1.0,0.5$ and 0.33 , respectively compared to the no sill case. Through this figure, it can be noticed that, for $L_{s} L=0.8$ as the sill height increases the local scour depth decreases and vice versa. This result can be explained using Fig. 11, which presents the relationship between the relative bed velocity at the end of stilling basin and Froude number for the different relative heights of sill. It was found that, the small height of sill leads to generate higher values of near bed velocity at the end of stilling basin. In addition for larger heights of sill, the absolute near bed velocity is smaller compared to the lesser ones.

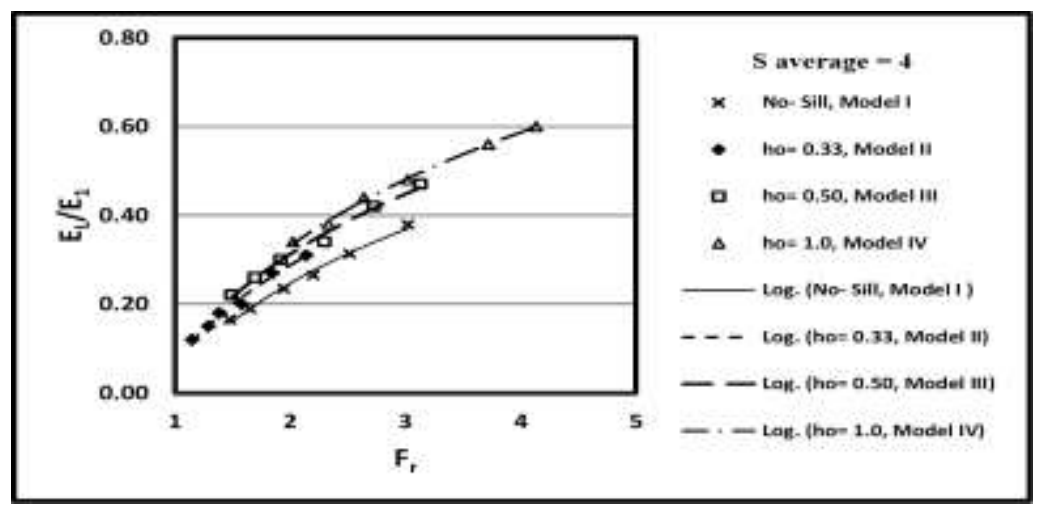

Fig. 7. Relationship between energy dissipation $E_{L} / E_{l}$ and Froude number $F_{r}$ for different relative heights of sill and $L_{s} / L=0.8$.

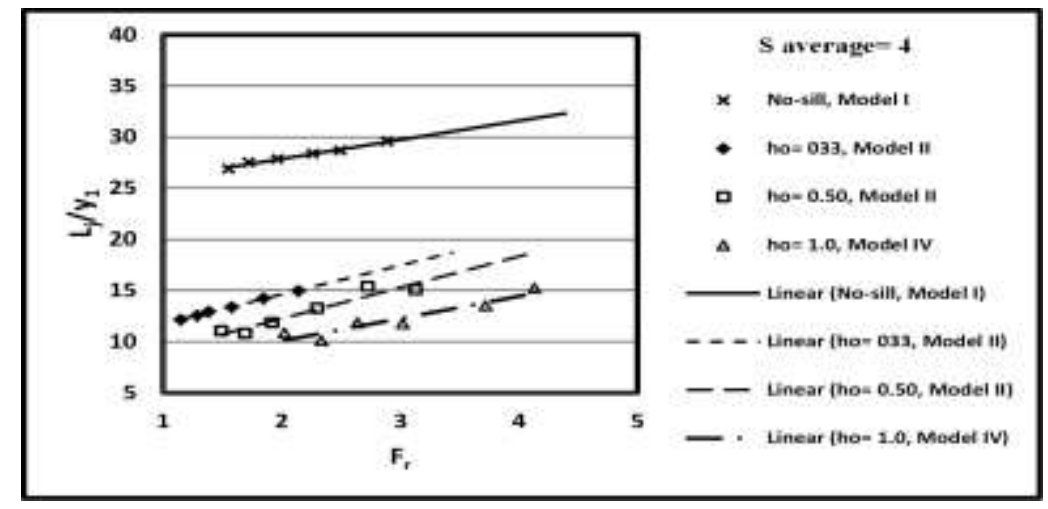

Fig. 8. Relationship between $L_{j} / y_{l}$ and $F_{r}$ for different relative heights of sill and $L_{s} / L=0.8$. 


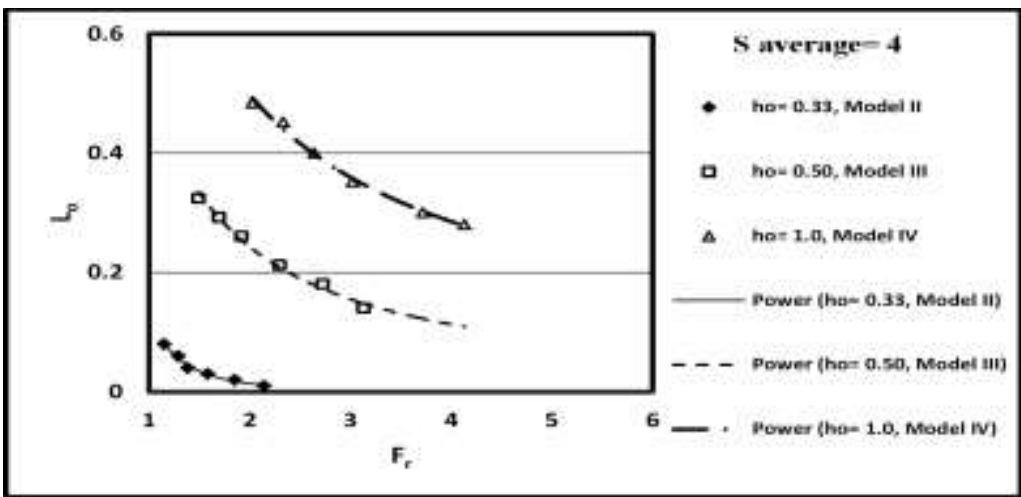

Fig. 9. Relationship between $L_{o}$ and $F_{r}$ for different relative heights of sill and $L_{s} / L=0.8$..

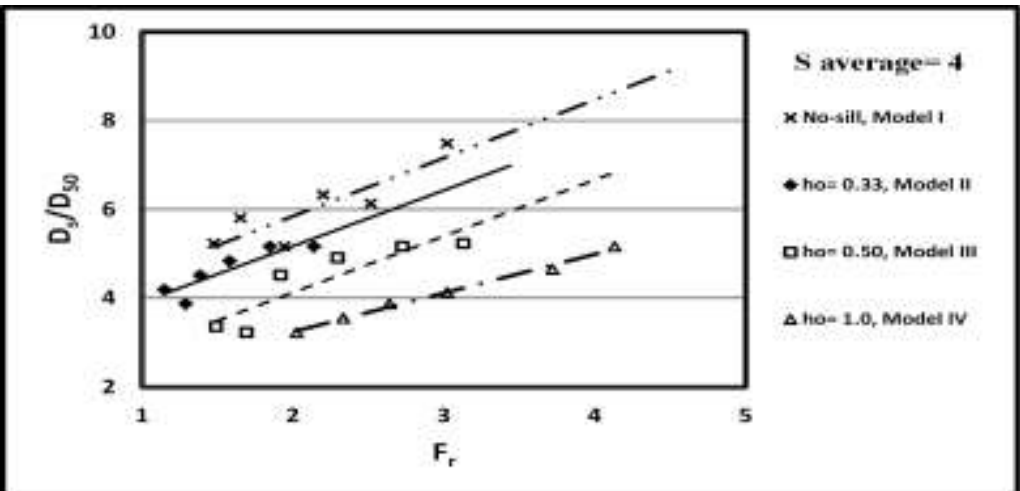

Fig. 10. Relationship between $D_{s} / D_{50}$ and $F_{r}$ for different relative heights of sill and $L_{s} / L=0.8$.

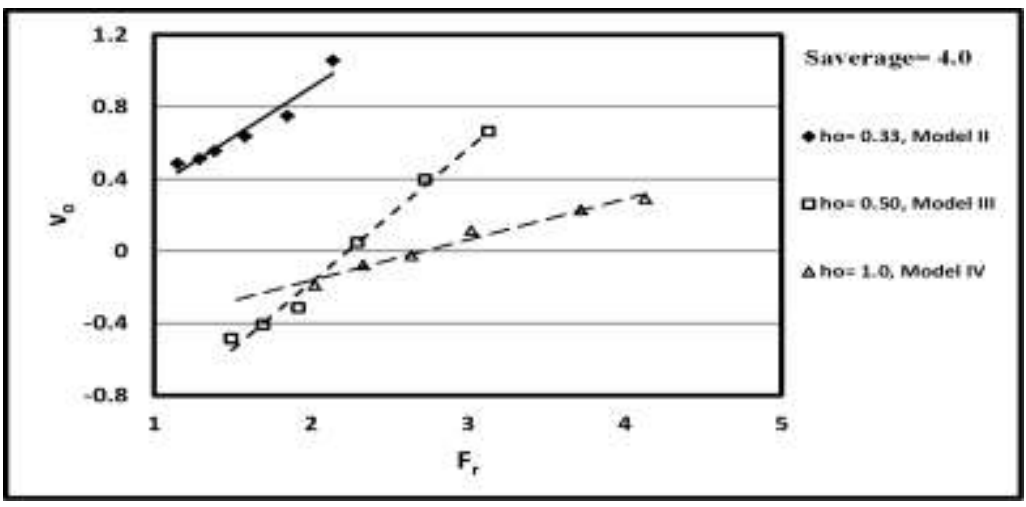

Fig. 11. Relationship between $v_{o}$ and $F_{r}$ for different relative heights of sill and $L_{s} / L=0.8$. .

\subsection{Sill configuration}

The effect of sill arrangements over stilling basin on flow characteristics is investigated at $L_{S} / L=0.8$ and $h_{o}=1.0$. Table (1) presents two models with the same sill height and position, Models IV and VI. For model IV the sill has right rectangular face in the upstream and slopped shape $(1 \mathrm{H}: 1 \mathrm{~V})$, in downstream face. For model VI the sill has sloped shape at the upstream face and right rectangular shape in the downstream face. The relationship between the energy dissipation and Froude number for both models IV and VI 
Yasser A. Mohamed et al., studying the effect of different configurations and positions of sill ..........

is presented in Fig. 12. This figure presents two average submergence ratios ( $S=4$ and 5), in addition to the no-sill cases. It was found that, for all sill configurations (Models IV and VI) sill over stilling basin leads to produce more energy dissipations compared to the nosill case as clarified in section 4.1. Model IV produces higher energy dissipation compared to model VI for all tested average submergence ratios, $(S=4$ and 5).The values of energy dissipation for model IV are $30 \%$ and $61 \%$ for average submergence ratios $\mathrm{S}=4$, and 5 respectively. While these ratios for Model VI are $7 \%$ and $20 \%$ for $\mathrm{S}=4$ and $\mathrm{S}=5$ respectively. Relative length of submerged jump is shorter for all sill configurations compared to the no-sill case, see Fig. 13. It was found also that, model IV produces shorter length for submerged jump compared to model VI. The relative length of submerged hydraulic jump for model IV is reduced by $58 \%$ and $45 \%$ for average submergence ratios $\mathrm{S}=4$, and 5 respectively. While for Model VI, the length of submerged hydraulic jump is reduced by $30 \%$ and $13 \%$ for $\mathrm{S}=4$, and $\mathrm{S}=5$ respectively. The last observations prove that, the right face upstream of sill is better than the slope face in the upstream. This configuration of sill has the ability to more damp and control the velocity jet behind radial gat, leading to produce shorter length of submerged jump and gain higher dissipation of energy. The relative reverse length $L_{o}$ versus Froude number was presented in Fig. 14. It was found that model IV has longer lengths of $L_{o}$ compared to model VI. Figure 15 shows the relative scour depth $\left(\mathrm{D}_{\mathrm{s}} / \mathrm{D}_{50}\right)$, versus Froude number $F_{r}$ for both models IV and VI in addition to the no-sill cases for average submergence ratios $S=4$ and 5 . It was found that model VI has higher values of local scour depth compared to model IV. These results can be explained using Figs. 14 and 16. At which the longer reverse length for model IV has smaller absolute values of near bed velocity at the end of stilling basin compared to model VI which has small length of reveres flow with higher values of near bed velocity. At which, the small value of near bed velocity produces lower values of local scour depth. The local scour depth was reduced by $42 \%$ and $36 \%$ for models IV and VI, respectively.

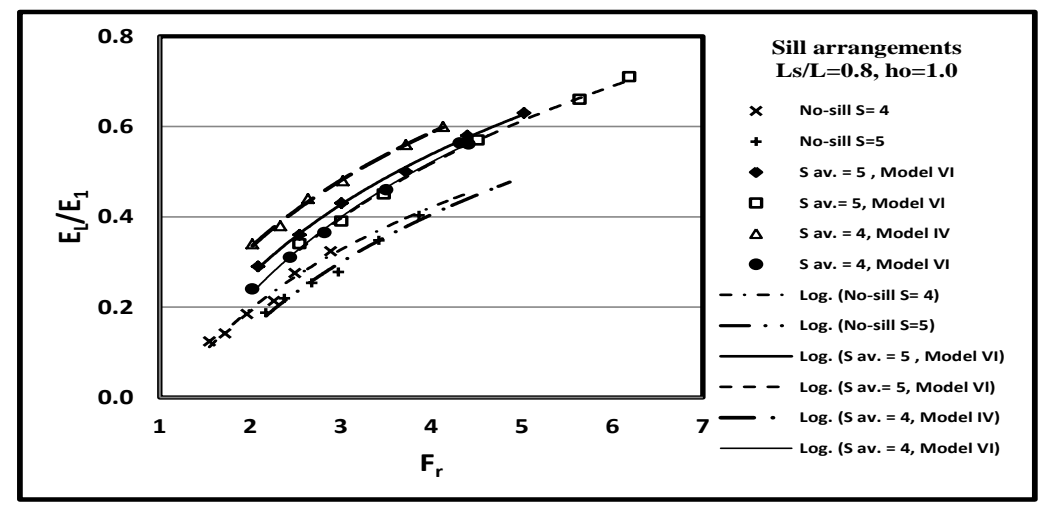

Fig. 12. Relationship between energy dissipation $E_{L} / E_{l}$ and Froude number $F_{r}$ for different sill arrangements. 


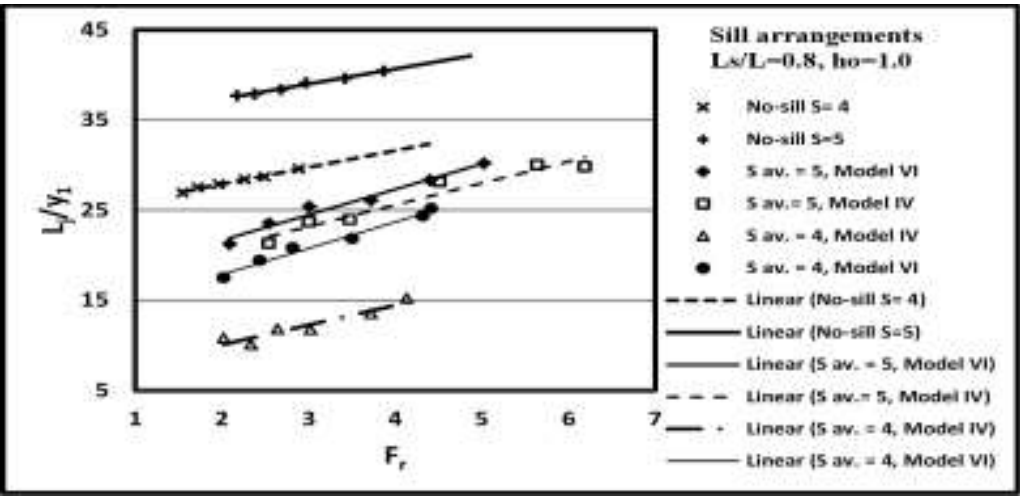

Fig. 13. Relationship between $L_{j} / y_{1}$ and $\mathrm{F}_{\mathrm{r}}$ for different arrangements of sill.

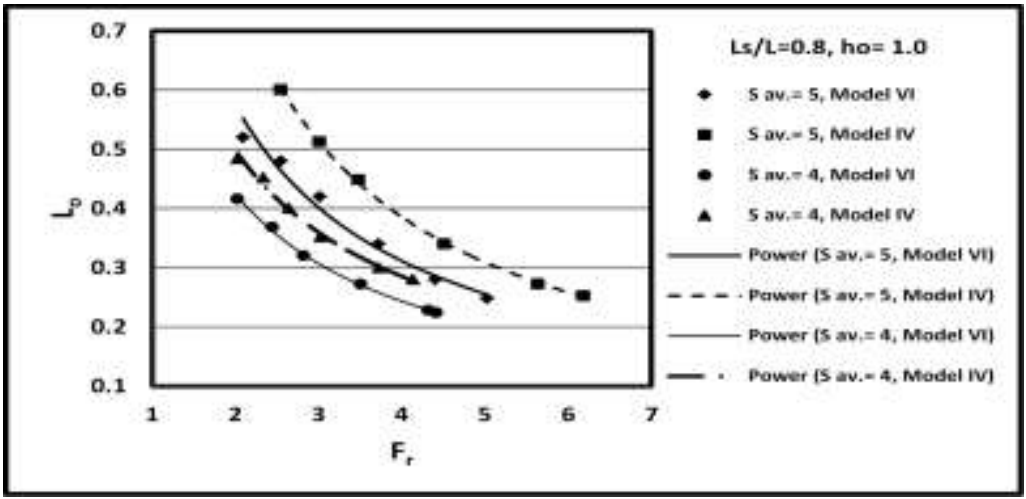

Fig. 14. Relationship between $L_{o}$ and $F_{r}$ for different sill arrangements.

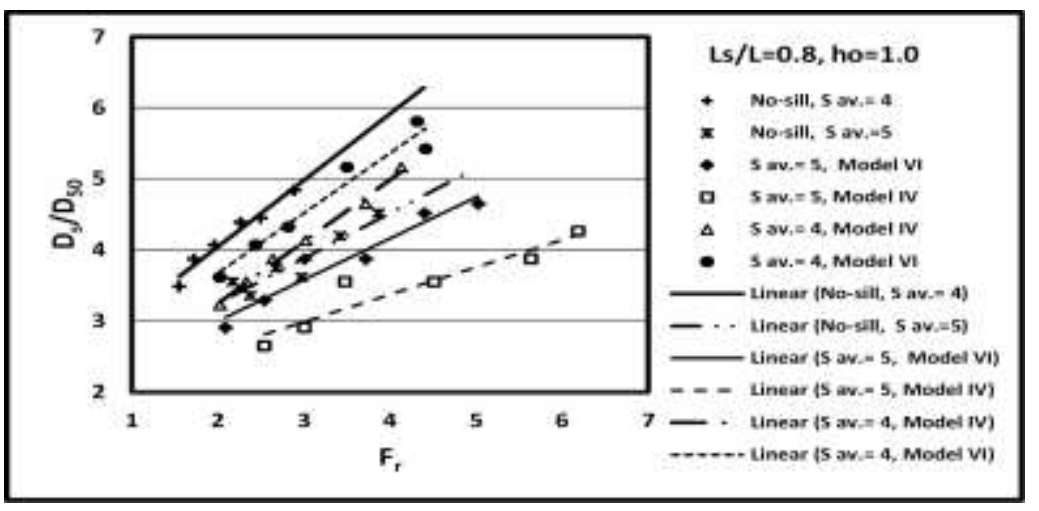

Fig. 15. Relationship between $D_{s} / D_{50}$ and $F_{r}$ for different sill arrangements. 


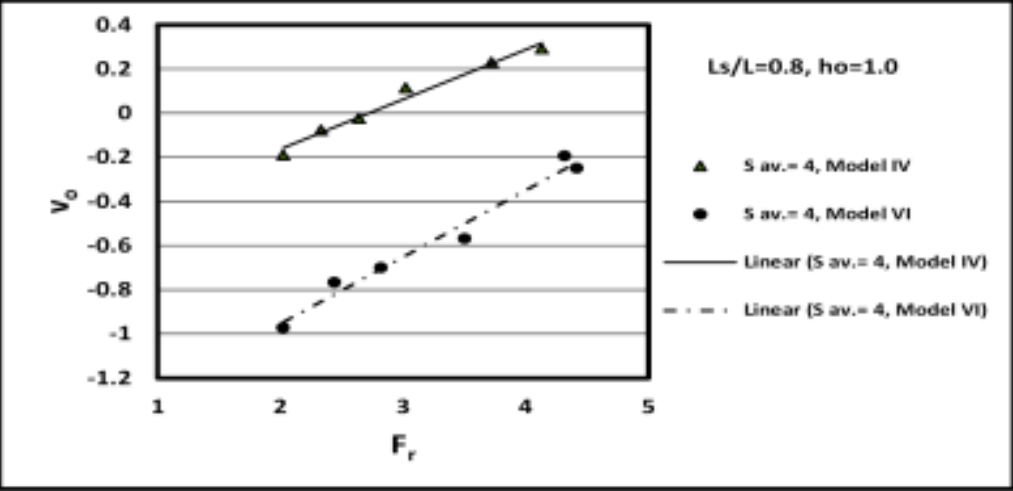

Fig. 16. Relationship between $v_{o}$ and $F_{r}$ for different sill arrangements.

\subsection{Sill position}

There are three models (V, VI, and VII), present the different positions of sill over stilling basin. The relative positions of sill $L_{s} / L$ were $1.0,0.8$, and 0.6 . The relative sill height was fixed $\left(\mathrm{h}_{\mathrm{o}}=1.0\right)$. The effect of different sill positions on flow characteristics are shown in Figs, 17 through 21. It was found that the sill position $L_{s} / L=0.6$ produces maximum relative energy loss, shorter length of submerged jump, and minimum local scour depth compared to the other positions and no-sill cases, Figs. 17, 18 and 20. Moreover, as the sill moves closer to the end of stilling basin the minimum energy dissipation, longer length of submerged jump and maximum local scour depth are obtained. Figure 19 presents $L_{o}$ versus Froude number for different $L_{S} / L$. it was observed that as $L_{S} / L$ decreases the length of reverse flow $L_{o}$ decreases and vice versa. But as the reverse length increases, for the same flow conditions, the near bed velocity at the end of stilling basin decreases, Fig. 21. This result for near bed velocity explains the generated values of local scour depth downstream stilling basin. The length of submerged hydraulic jump and relative scour depth at $L_{s} / L=0.6$ are reduced by $42 \%$ and $62 \%$ while the energy dissipation is increased by $25 \%$ compared to the no-sill case. As the sill moves to be close to radial gate, the sill ability to control the submerged get propagation behind the radial gate increased. Hence shorter length of jump, smaller values of local scour depth and higher energy dissipation are obtained.

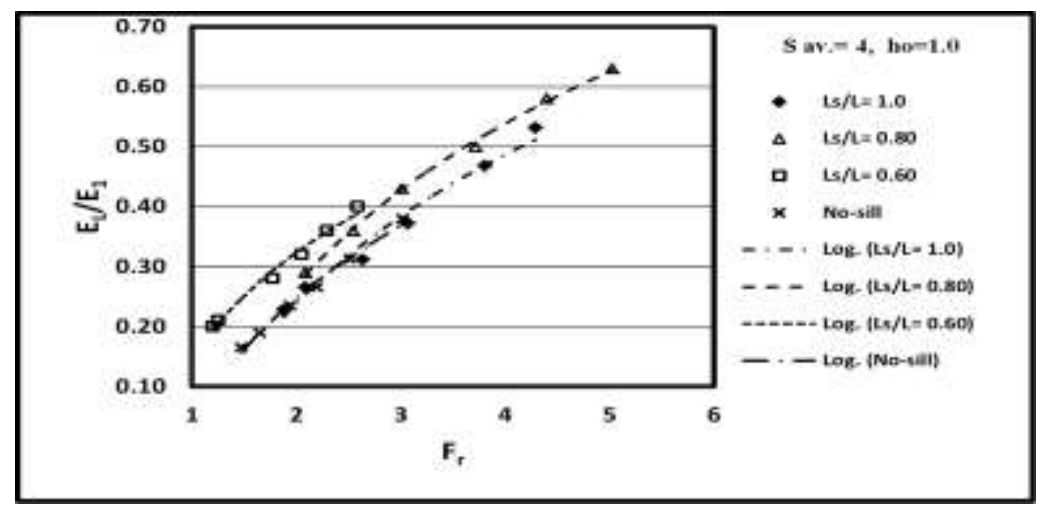

Fig. 17. Relationship between energy dissipation $E_{L} / E_{l}$ and Froude number $F_{r}$ for different sill positions with sloped face at the upstream. 


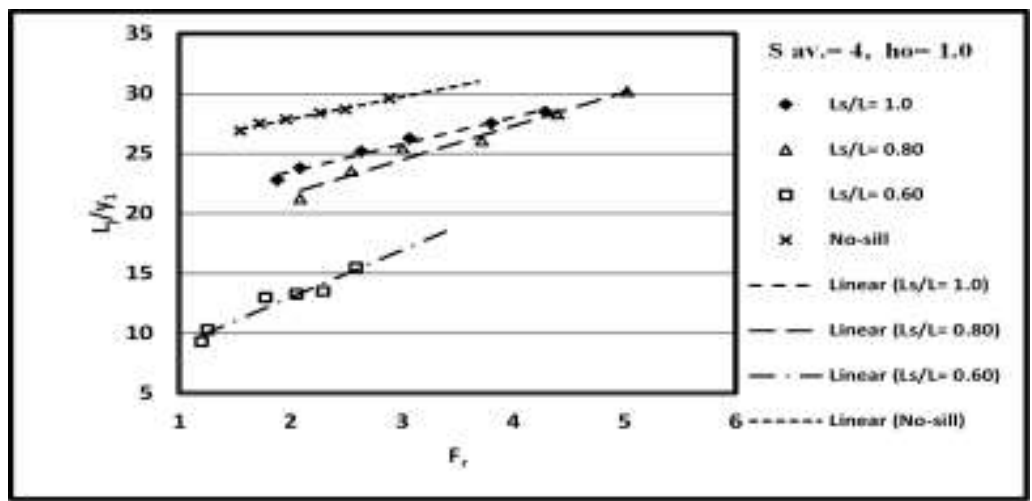

Fig. 18. Relationship between $L_{j} / y_{l}$ andF for different $L_{s} / L$ with sloped face at the upstream.

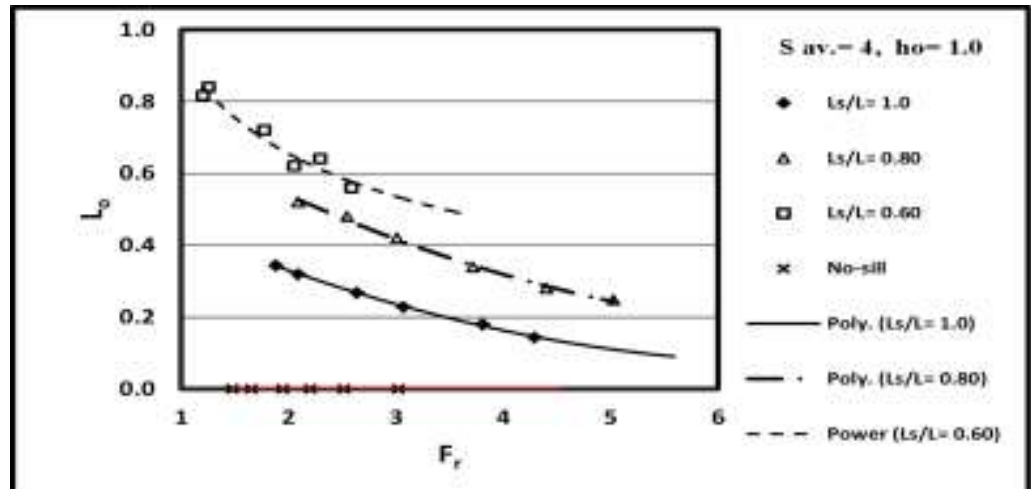

Fig. 19. Relationship between $L_{o}$ and $F_{r}$ for different $L_{S} / L$ with sloped face at the upstream.

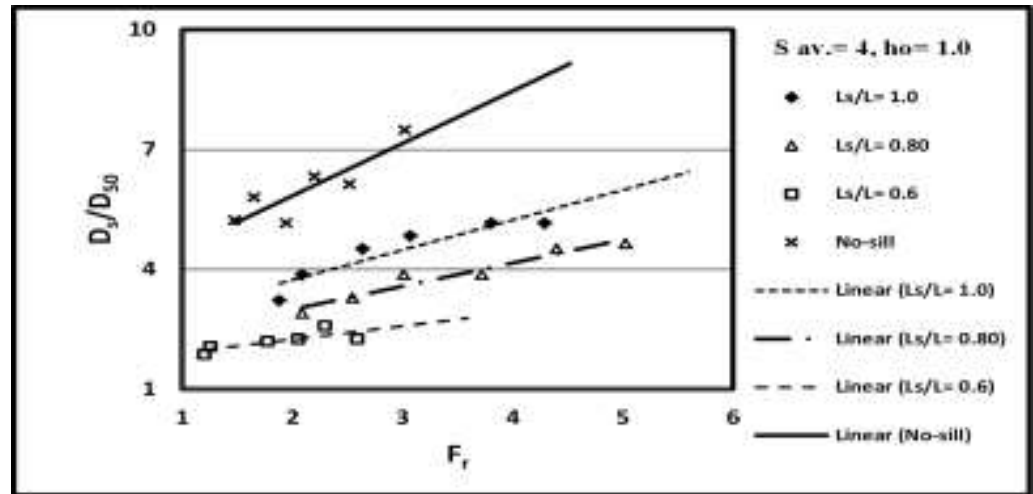

Fig. 20. Relationship between $D_{s} / D_{50}$ and $F_{r}$ for different $L_{s} / L w i t h$ sloped face at the upstream. 
Yasser A. Mohamed et al., studying the effect of different configurations and positions of sill

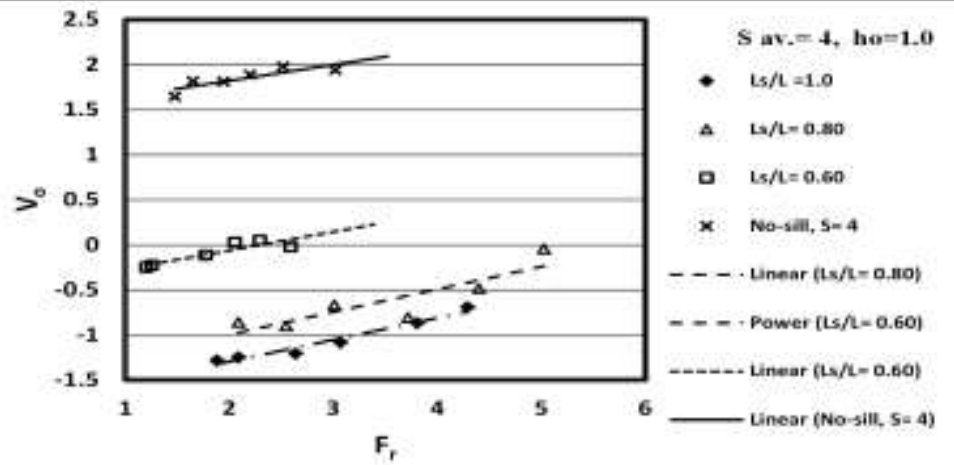

Fig. 21. Relationship between $v_{o}$ and $F_{r}$ for different $L_{s} / L$ with sloped face at the upstream.

\section{Statistical analysis}

Multiple linear regressions are used to correlate the dependent parameters with other independent ones as follow;

$$
Y=C+X_{1} F_{r}+X_{2} S+X_{3} h_{o}+X_{4} L_{s} / L+X_{5} \theta_{1}+X_{6} \theta_{2}
$$

Where, $Y$, represents the dependent parameters as $E_{L} / E_{1}, L_{j} / y_{1}, D_{s} / D_{50}$ and $L_{o} ; C$, is the intercept of Eq.3 with vertical axis; and $X_{1}$ through $X_{6}$ are the coefficients of the independent parameters; and $\square_{l}$ and $\square_{2}$ are the upstream and downstream angles of sill, respectively. Table 3 presents the coefficients of Eq. 3. Figures 22 through 25, presents the predicted values for different dependent parameters versus both of measured data and residuals. The results of these figures and Table (3) indicate that the proposed equations are express well the measured data for $E_{L} / E_{1}, L_{j} / y_{1}, D_{s} / D_{50}$ and $L_{o}$.

Table 3.

Regression coefficients of Eq. 3

\begin{tabular}{|c|c|c|c|c|c|c|c|c|c|}
\hline$Y$ & $C$ & $X_{I}$ & $X_{2}$ & $X_{3}$ & $X_{4}$ & $X_{5}$ & $X_{6}$ & $\begin{array}{c}\text { Standard } \\
\text { Error }\end{array}$ & $\mathrm{R}^{2}$ \\
\hline $\mathrm{E}_{\mathrm{L}} / \mathrm{E}_{1}$ & 0.025 & 0.11 & -0.008 & -0.051 & -0.009 & 0.023 & 0.016 & 0.03 & $94 \%$ \\
\hline $\mathrm{L}_{\mathrm{j}} / \mathrm{y}_{1}$ & 5.03 & 2.69 & 4.15 & 5.31 & -2.31 & -3.76 & -1.39 & 3.01 & $87 \%$ \\
\hline $\mathrm{D}_{\mathrm{s}} / \mathrm{D}_{50}$ & 5.82 & 0.24 & -0.30 & -3.10 & -0.16 & -0.42 & 0.06 & 0.40 & $89 \%$ \\
\hline $\mathrm{L}_{\mathrm{o}}$ & -0.11 & -0.02 & 0.03 & 0.017 & -0.01 & 0.33 & -0.09 & 0.10 & $78 \%$ \\
\hline
\end{tabular}
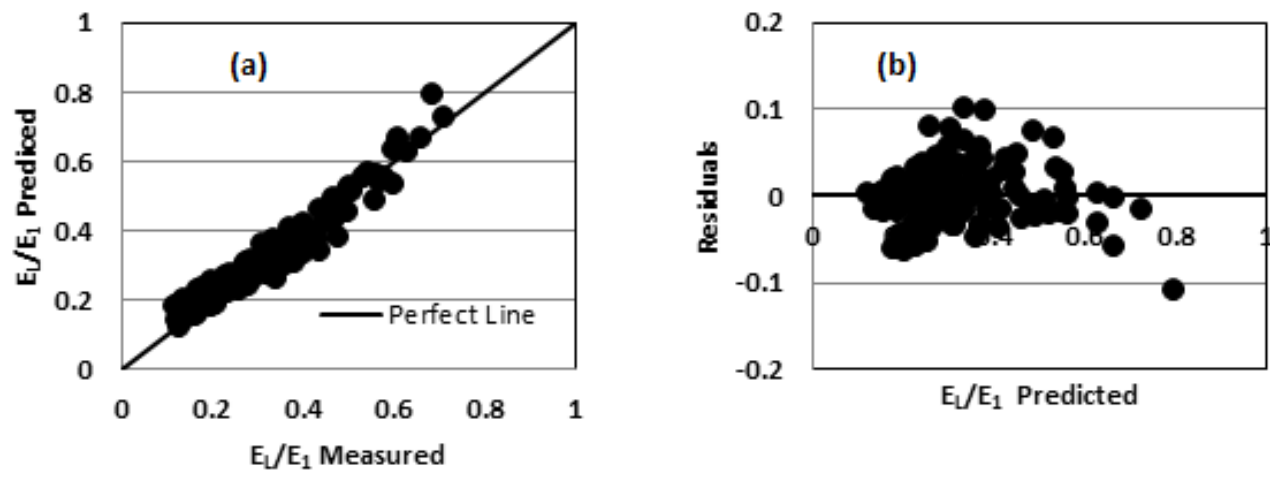

Fig. 22. Predicted versus measured data (a) and residuals (b) for $E_{L} / E_{l}$ 

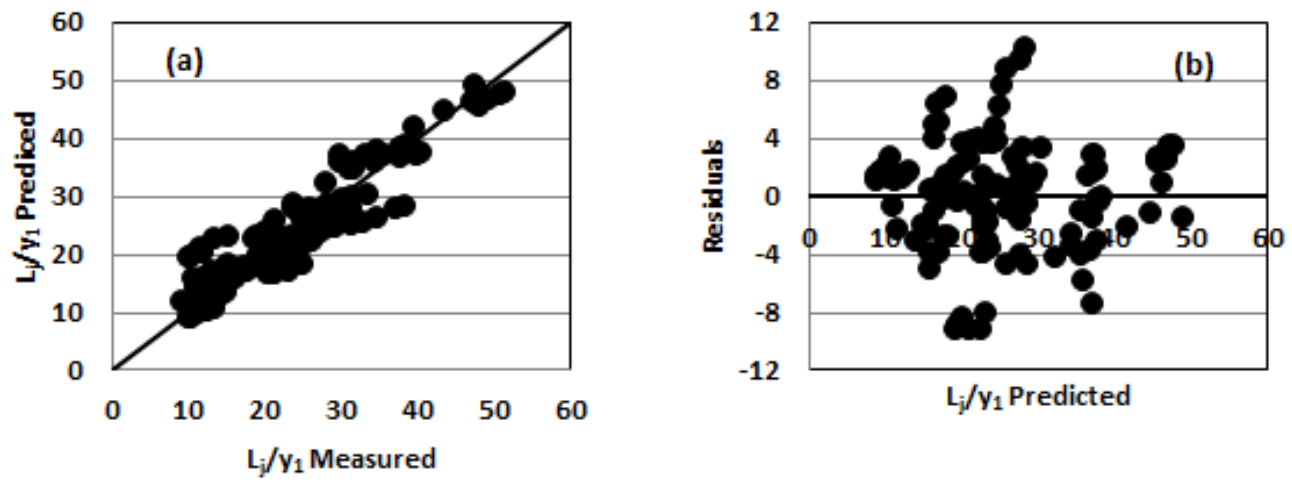

Fig. 23. Predicted versus measured data (a) and residuals (b) for $L_{j} / y_{1}$
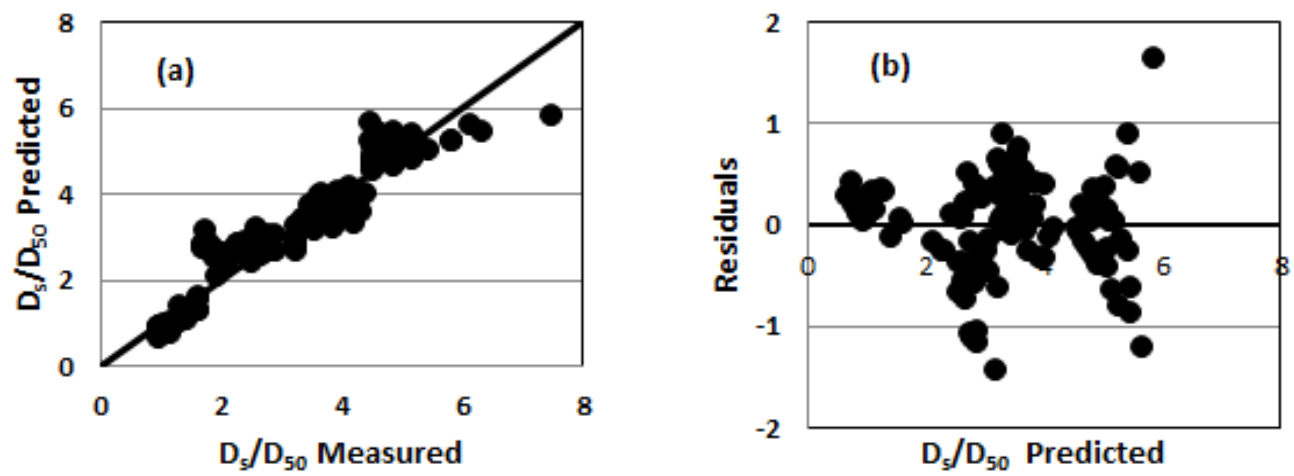

Fig. 24. Predicted versus measured data (a) and residuals (b) for $D_{s} / D_{50}$
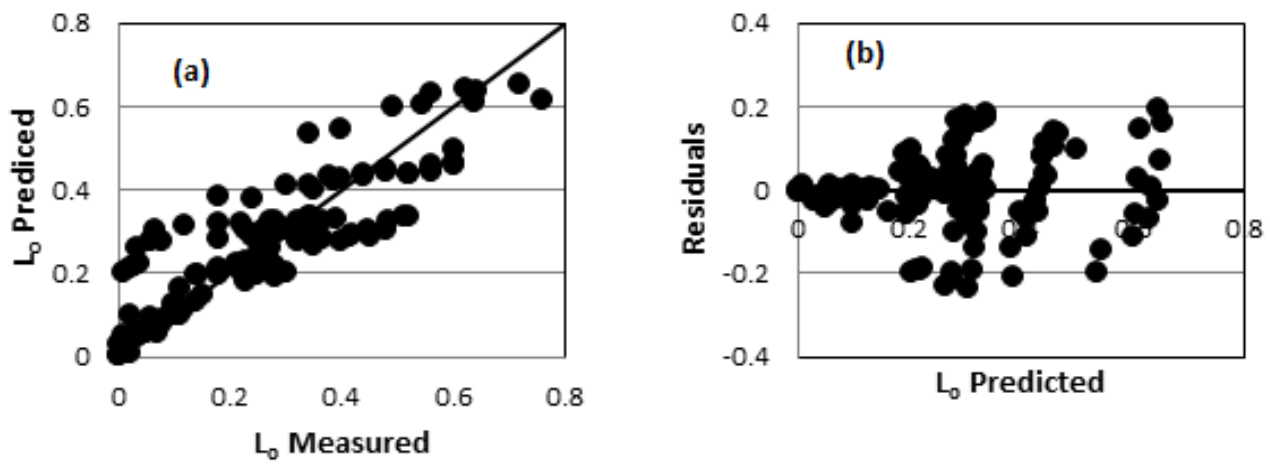

\section{Conclusion}

From this study, the following conclusions could be summarized as follow:

1- The sill over stilling basin has a great effect on flow characteristics and could share in the long time stability for such these huge hydraulic structures compared to the no sill case.

2- The reverse flow length downstream sill decreases as $F_{r}$ and submergence ratio increase.

3- The reverse flow length downstream sill increases as the relative sill height increases at the same $L_{S} / L$. In addition, it increases as $L_{S} / L$ decreases at the same $h_{o}$. 
Yasser A. Mohamed et al., studying the effect of different configurations and positions of sill ..........

4- The relative energy loss and relative length of submerged hydraulic jump increase as the Froude number increases for all experimental models and different submergence ratios.

5- Sill with right upstream and slopped faces (1H:1V) at downstream, increases energy dissipation by $23 \%$, and decreases submerged length of hydraulic jump and local scour depth downstream stilling basin by $28 \%$ and $8 \%$, respectively compared to the case of slopped face upstream sill at $L_{s} / L=0.8$, and $h_{o}=1.0$.

6- For sill with right upstream face, the length of submerged hydraulic jump is decreased by $59 \%$ for $L_{s} / L=0.8$ and $h_{o}=1.0$, and that will lead to a decrease of the stilling basin length.

7- For sill with right upstream face, energy dissipation is increased by $30 \%$ and relative scour depth decreased by $43 \%$ compared to the no sill case for $L_{s} / L=0.8$ and $h_{o}=1.0$.

8- For sill with sloped upstream face $L_{S} / L=0.6$ and $h_{0}=1.0$, energy dissipation is increased by $25 \%$ and relative scour depth and relative length of jump are decreased by $62 \%$ and $42 \%$, respectively, compared to the no sill case.

9- Equations for predicting $E_{L} / E_{l}, L_{j} / y_{1}, D_{s} / D_{50}$ and $L_{o}$ are developed.

\section{REFERENCES}

[1] Hager, W. H. (1992). Energy dissipators and hydraulic jump, Kluwer London.

[2] Rajaratnam, N. (1965). Submerged hydraulic jump. J. Hydraul. Div., 91 (4), 71-96.

[3] Rajaratnam, N. (1967). Hydraulic jumps. Advances in hydroscience, (4), 197-280, Academic Press, New York.

[4] GovindaRao, N.S. and Rajaratnam, N. (1963). The submerged hydraulic jump. Journal of Hydraulic Division, ASCE, 89 (1), 139-163.

[5] Narasimhan, S., and Bhargara P. (1976). Pressure fluctuations in submerged jump. $J$. Hydraul. Div., ASCE. 102 (3), 339-350.

[6] McCorquodale, J.A., and Khalifa, Abdelkawi M. (1980).Submerged radial hydraulic jump. Hydraul. Div., ASCE. 106 (3), 355-367.

[7] El-Azizi, I. (1985).A study of submerged hydraulic jump stilling basins of low head irrigation structures. M.Sc. Thesis, Faculty of Engineering, Ain Shams University, Egypt.

[8] Abdel-Aal G.M.,(2004). Modeling of rectangular submerged hydraulic jump. AEJ, 43(6), 847-855.

[9] Long, D., Steffler, P.M., and Rajaratnam, N. (1991). A numerical study of flow structure in submerged jumps. J. Hydraul Res., 29 (3), 293-307.

[10] Fuxima and Prinos, P. (1999). Characteristics of submerged hydraulic jump. Proc. of XXV III congress, Graz.

[11] Ma, F., Hou, Y., and Prinos, P. (2001). Numerical calculation of submerged hydraulic jumps. J. Hydraul Res., 39 (5), 493-503.

[12] Smith, C.D. (1989). The submerged hydraulic jump in an abrupt lateral expansion. $J$. Hydraul Res., ASCE, 27 (2), 257-266.

[13] Ohtsu, I., Yasuda and Ishkikawa, M. (1999). Submerged hydraulic jump below abrupt expansion. J. Hydraul Res., ASCE, 125 (5), 492-499.

[14] Flokstra (2006). Modelling of submerged vanes. J. Hydraul Res., 44(5), 591-602.

[15] Brett L. Vallé, and Gregory B. Pasternack (2006). Submerged and un-submerged natural hydraulic jumps in a bedrock step-pool mountain channel. Journal of Geomorphology, 82, 146-159.

[16] SubhasishDey and ArindamSarkar (2008). Characteristics of turbulent flow in submerged jumps on rough beds. Journal of Engineering Mechanics, 134 (1), 49-59.

[17] Ali, A.M., Mohamed, Y.A., (2010). Effect of stilling basin shape on the hydraulic characteristics of the flow downstream radial gates. AEJ, 49, 393-400 
[18] Ali, N.A. (1995). The proper location of sill with scour reach downstream of heading-up structure. Bulletin of the Faculty of Engineering, Assuit University, Egypt. 23 (2),11-19.

[19] Habibzadeh, A., Wu, S., Ade, F., Rajaratnam, N., and Loewen, M.R., (2001). Study of submerged hydraulic jumps with blocks. J. Hydraul. Eng. 137, 706-710

[20] Hassan, N.M.K., and Narayanan, R. (1986). Local scour downstream of an apron. J. Hydraul. Eng., 111 (11), 1371-1385.

[21] Habib, E., Mosa, M., and Petrillo, A. (1994). Scour downstream of hydraulic jump. Proc. of Hydropower and Dams Conf., Budapest, Hungary.

[22] El-Gamel, M.M., Ragih, O.S., Sobieh, M.M., and El Abd, S.M. (2002). Experimental study of local scour downstream stilling basins. Mansora Engineering Journal, Faculty of Engineering, Mansora University, Egypt. 27 (4), 90-106.

[23] El-Gamel, M.M. (2001). Effect of using three-lines of angle baffles on scour downstream heading-up structures. Mansora Engineering Journal, Faculty of Engineering, Mansora University, Egypt. 26(2), 73-85.

[24] Saleh, O.K., Negm, A.M., Waheed-Eldin, O.S., and Ahmad, N.G. (2003). Effect of end sill on scour characteristics downstream of sudden expanding stilling basins. Proc. of $6^{\text {th }}$ International River Eng. Conf. Pub. On CD ROM and Booklet of Abstracts, Ahvaz, Iran.

[25] SubhasishDey and ArindamSarkar (2006).Scour downstream of an apron due to submerged horizontal Jets. J. Hydraul. Eng., 132(3), 246-257.

[26] Tiwari, H.L., Goel, A. and Gahlot, V.K. (2011). Experimental study of effect of end sill on stilling basin performance. International Journal of Engg. Sci. and Technology, 3(4), 3134-3140.

[27] AlirezaHabibzadeh, Mark R. Loewen, and NallamuthuRajaratnam (2012). Performance of baffle blocks in submerged hydraulic jumps. J. Hydraul. Eng., 138(10), 902-908.

[28] AlirezaHabibzadeh, Mark R. Loewen, and NallamuthuRajaratnam (2014). Mean flow in a submerged hydraulic jump with baffle blocks. J. Eng. Mech., 140(5), 04014020.

[29] Chen,J.G., Zhang, J. M., Xu, W. L. , and Peng, Y., (2014). Characteristics of the velocity distribution in a hydraulic jump stilling basin with five parallel offset jets in a twin-layer configuration. J. Hydraul. Eng., 140(2), 208-217.

[30] Tiwari, H.L. (2013). Design of stilling basin with impact wall and end sill. International Research Journal of Resent Sciences, 2(3), 59-63.

[31] Tiwari, H.L. and TiwariSeema (2013). Design of stilling basin models with intermediate sill. Journal of Science, Technology and Management, 2(4), pp.66-71.

[32] Tiwari, H.L, Gahlot, V.K. and TiwariSeema (2013). Reduction of scour depth downstream of stilling basin. International Research Journal of Engineering Sciences: vol.2 (7). Pp.20- 25.

[33] Tiwari, H.L. Pawar A., Gehlot, B .K..and Singh, J. (2014). Study of shape of intermediate sill on the design of stilling basin model. International Journal of Research in Engg and Techonolgy (IJRET), 3 (4),133-138

[34] Henderson, F.M., (1989). Open channel flow. Macmilan publishing co., New York.

[35] Chow, V. (1959). Open-channel hydraulics, McGraw-Hill, New York. 
Yasser A. Mohamed et al., studying the effect of different configurations and positions of sill ..........

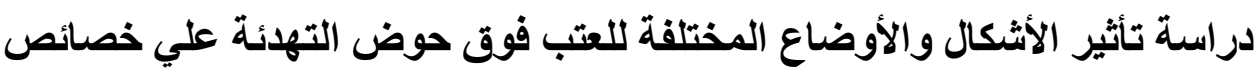

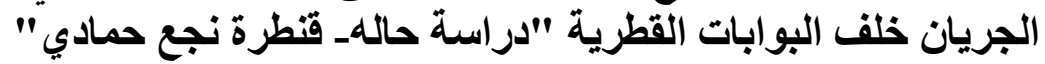

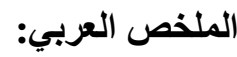

تعتبر القناطر الكبرى واحدة من أهم المنشآت الهيدروليكية والتي يتم توظيفها للتحكم في كمية التذفقات وكذا مناسيب

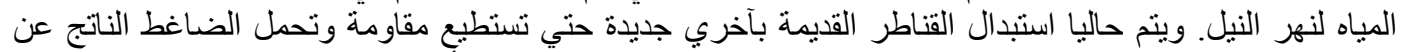

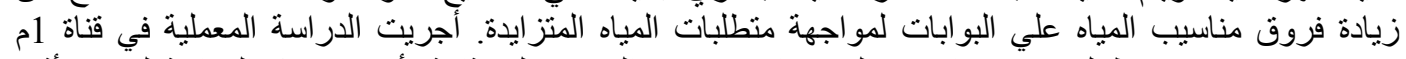

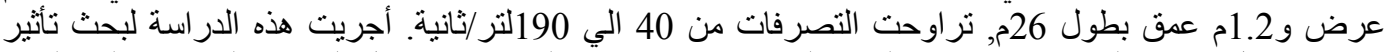

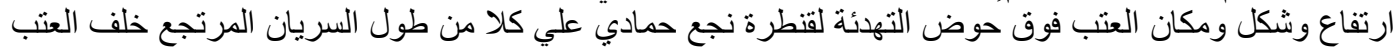

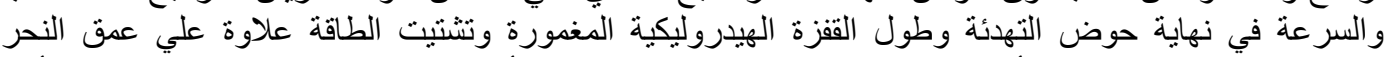

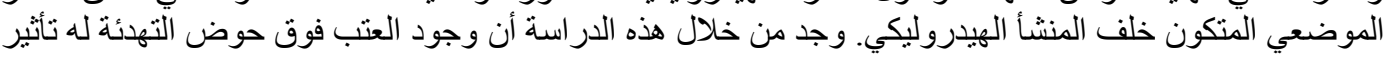

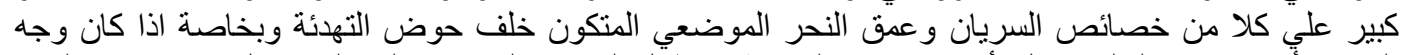

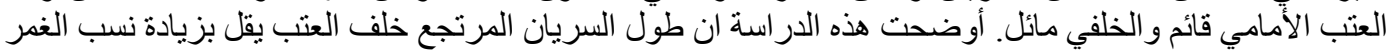

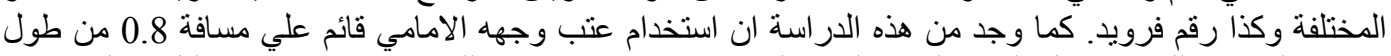

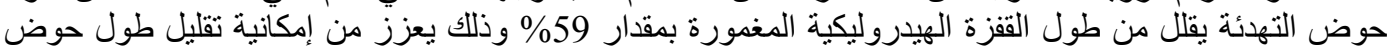

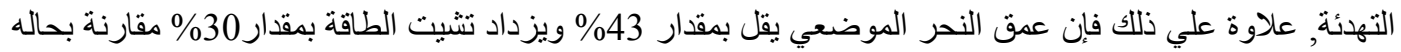

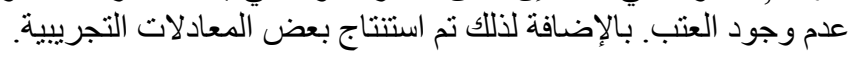

